\title{
EVALUASI REAKSI PESERTA PADA PENYELENGGARAAN DIKLAT DASAR JABATAN FUNGSIONAL PENYULUH PERIKANAN DI BALAI DIKLAT APARATUR KEMENTERIAN KELAUTAN DAN PERIKANAN
}

\author{
Yudistira Adi Nugroho \\ e-mail: yudistiraadinugroho09@gmail.com \\ Balai Diklat Aparatur Kementerian Kelautan dan Perikanan
}

\begin{abstract}
Abstrak: Tujuan penelitian ini adalah untuk mengetahui dan menganalisis reaksi pesertapada penyelenggaraan Diklat Dasar Jabatan Fungsional Penyuluh Perikanan di Balai Diklat Aparatur Kementerian Kelautan dan Perikanan, dengan menggunakan model Kirkpatrick. Metode yang digunakan pada penelitian ini adalah metode deskriptif kualitatif. Pengumpulan data dilakukan dengan menggunakan pedoman observasi dan menyebarkan kuesioner. Analisis data menggunakan teknik komparatif dengan rentang skala, yaitu membandingkan kualitas penyelenggaraan Diklat Dasar Jabatan Fungsional Penyuluh Perikanan Tingkat Ahli dengan Diklat Dasar Jabatan Fungsional Penyuluh Perikanan Tingkat Terampil. Hasil penelitian menunjukkan bahwa kurikulum, tempat belajar, dan asrama pada penyelenggaraan Diklat Dasar Jabatan Fungsional Penyuluh Perikanan Tingkat Ahli sudah sangat baik, sedangkan layanan panitia, menu makanan, dan pengaturan waktu masih perlu ditingkatkan. Untuk kurikulum, tempat belajar, asrama, layanan panitia, menu makanan, dan pengaturan waktu pada penyelenggaraan Diklat Dasar Jabatan Fungsional Penyuluh Perikanan Tingkat Terampil seluruhnya masih perlu ditingkatkan.
\end{abstract}

Kata-kata kunci: penyuluh perikanan, diklat, evaluasi

\section{EVALUATION OF PARTICIPANT'S REACTIONS ON THE IMPLEMENTATION OF BASIC TRAINING OF FUNCTIONAL POSITION OF FISHERY'S EXTENSION WORKERS IN THE TRAINING OFFICE FOR APPARATUS OF THE MINISTRY OF MARINE AFFAIRS AND FISHERIES}

\begin{abstract}
The purpose of this study is to explain the participants reactions with Kirkpatrick model on the implementation of Basic Training of Functional Position of Fisheries Extension Workers at the Training Office for Apparatus of the Ministry of Marine Affairs and Fisheries. For research purposes, the method used in this research is the qualitative descriptive method. Instrument data collection used is the result of observation and questionnaires distributed to respondents. Data analysis using comparative techniques with scale range, that is the comparing the quality of implementation Basic Training of Functional Position Fishery's Extension workers in expert level with Basic Training of Functional Position of Fisheries Extension Worker in proficient level. The results showed the reaction of participants using the Kirkpatrick model known that the curriculum, place of study, and dormitory in the implementation of Basic Training of Functional Position of Fisheries extension Workers in Expert Level have been very good while service of the committee, food menu, and time management still needs to be improved. For the curriculum, place of study, dormitory, service of the committee, food menu, and time management in the implementation of Basic Training of Functional Position of Fishery's extension workers in Proficient Level still needed to be improved.
\end{abstract}

Keywords: fishery instructor, training, evaluation 


\section{PENDAHULUAN}

Dalam rangka mewujudkan visi Kementerian Kelautan dan Perikanan, yaitu "Terwujudnya pengelolaan sumber daya kelautan dan perikanan secara berdaulat, mandiri dan berkelanjutan untuk kemakmuran rakyat" membutuhkan peran serta seluruh komponen bangsa baik itu masyarakat maupun aparatur kelautan dan perikanan. Bagi aparatur kelautan dan perikanan, salah satu hal yang dapat dilakukan adalah dengan menyelenggarakan kegiatan penyuluhan yang sistematis, efektif dan efisien.

Penyuluhan adalah proses pembelajaran bagi pelaku utama serta pelaku usaha agar mereka mau dan mampu menolong dan mengorganisasikan dirinya dalam mengakses informasi pasar, teknologi, permodalan, dan sumber daya lainnya, sebagai upaya untuk meningkatkan produktivitas, efisiensi usaha, pendapatan, dan kesejahteraannya, serta meningkatkan kesadaran dalam pelestarian fungsi lingkungan hidup, (UU Nomor 16 tahun 2006). Penyuluhan sebagai proses pemberdayaan masyarakat memiliki tujuan utama yang tidak terbatas pada terciptanya "better-farming, better business, dan better living, tetapi untuk memfasilitasi masyarakat (sasaran) untuk mengadopsi strategi produksi dan pemasaran agar mempercepat terjadinya perubahan-perubahan kondisi ekonomi sehingga mereka dapat meningkatkan taraf hidup pribadi dan masyarakatnya (dalam jangka panjang) (Slamet, 2000).

Merujuk pada hal tersebut maka komponen yang paling esensial dalam penyelenggaraan kegiatan penyuluhan adalah penyuluh perikanan. Penyuluh perikanan memiliki peran sebagai pendamping sekaligus mitra sejati pelaku utama dan pelaku usaha perikanan dalam mengembangkan usaha perikanan. Dalam Peraturan Menteri Negara Pendayagunaan Aparatur Negara Nomor 19 tahun 2008 tentang Jabatan Fungsional Penyuluh Perikanan dan Angka Kreditnya menjelaskan bahwa tugas pokok penyuluh perikanan adalah melakukan kegiatan penyuluhan perikanan yang meliputi persiapan, pelaksanaan, evaluasi dan pelaporan serta pengembangan penyuluhan perikanan.

Dalam melaksanakan tugas pokok tersebut penyuluh perlu memiliki dan meningkatkan berbagai pengalaman dalam membawa pesan dan mendiseminasikan teknologi kepada para pelaku utama. Agar terbentuk penyuluh perikanan yang profesional sesuai dengan tugas jabatannya, maka para penyuluh sebelumnya harus mengikuti dan lulus diklat dasar atau diklat pembentukan. Dalam momentum tersebut, para penyuluh akan ditatar dan dibekali berbagai kompetensi yang akan berguna pada saat terjun ke lapangan untuk melaksanakan penyuluhan.

Peraturan Pemerintah Nomor 101 tahun 2000 tentang Diklat Bagi PNS menyebutkan bahwa tujuan pelaksanaan diklat adalah untuk (1) meningkatkan pengetahuan, keahlian, keterampilan, dan sikap untuk dapat melaksanakan tugas jabatan secara profesional dengan dilandasi kepribadian dan etika PNS sesuai dengan kebutuhan instansi; (2) menciptakan aparatur yang mampu berperan sebagai pembaharu dan perekat persatuan dan kesatuan bangsa; (3) memantapkan sikap dan semangat pengabdian yang berorientasi pada pelayanan, pengayoman, dan pemberdayaan masyarakat; dan (4) menciptakan kesamaan visi dan dinamika pola pikir dalam melaksanakan tugas pemerintahan umum dan pembangunan demi terwujudnya kepemerintahan yang baik. Sesuai dengan tujuan pelaksanaan diklat tersebut maka diharapkan penyuluh perikanan setelah mengikuti diklat dasar mendapatkan bekal kompetensi yang mendukung tugas jabatannya.

Dalam rangkaian pelaksanaan diklat, komponen evaluasi menjadi sangat penting untuk dilaksanakan. Penyelenggaraan diklat tidak langsung saja berakhir dengan ditutupnya kegiatan diklat. Beberapa permasalahan bisa saja baru teridentifikasi setelah berakhirnya kegiatan diklat. Misalnya, bagaimana kualitas program pelatihan dan apakah peserta merasa puas dengan program diklat yang baru saja selesai atau apakah ada hal-hal yang masih perlu atau harus ditingkatkan berkaitan dengan kualitas pelaksanaan program diklat. Seluruh pertanyaan di atas dapat dijawab jika penyelenggara diklat melakukan evaluasi terhadap program diklat tersebut. Evaluasi program dilakukan untuk menilai efektivitas dan efisiensi program. Menurut Kirkpatrick (2005), evaluasi diklat dilaksanakan dengan tiga alasan khusus, yaitu (1) untuk menentukan efektivitas suatu program diklat dan mendapatkan informasi untuk mengembangkan program diklat pada masa yang akan datang; (2) untuk menentukan 
apakah program diklat diteruskan, dimodifikasi, atau dihentikan; (3) untuk memberikan bukti nyata mengenai keberadaan lembaga pelatihan dengan menunjukkan kontribusinya terhadap sasaran serta tujuan perusahaan.

Diklat Dasar Jabatan Fungsional Penyuluh Perikanan sesuai dengan pedoman penyelenggaraan dibagi menjadi dua, yaitu jenjang keterampilan dan jenjang keahlian. Jenjang keterampilan diperuntukkan bagi calon penyuluh yang memiliki latar belakang pendidikan SMU atau Diploma sedangkan jenjang keahlian diperuntukkan bagi calon penyuluh yang memiliki latar belakang pendidikan minimal Strata 1 (S1).

Sesuai dengan pedoman penyelenggaraan diklat tersebut, Balai Diklat Aparatur sebenarnya telah melakukan evaluasi penyelenggaraan dengan membagikan kuesioner kepada peserta diklat. Namun hasil kuesioner tersebut belum dianalisis secara maksimal sehingga belum dirasakan manfaatnya dalam peningkatan kualitas penyelenggaraan diklat berikutnya. Untuk mengetahui dan menganalisis kualitas penyelenggaraan kedua diklat tersebut maka dalam penelitian ini penulis mengambil judul "Evaluasi Reaksi Peserta pada Penyelenggaraan Diklat Dasar Jabatan Fungsional Penyuluh Perikanan di Balai Diklat Aparatur Kementerian Kelautan dan Perikanan". Berdasarkan uraian pada latar belakang di atas maka rumusan masalah dalam penelitian ini adalah bagaimana evaluasi reaksi peserta pada penyelenggaraan Diklat Dasar Jabatan Fungsional Penyuluh Perikanan di Balai Diklat Aparatur Kementerian Kelautan dan Perikanan.

Sesuai dengan kebutuhan organisasi untuk melaksanakan evaluasi penyelenggaraan diklat dan adanya umpan balik dari peserta, maka ruang lingkup dalam penelitian ini hanya dibatasi pada level pertama dari Model Kirkpatrick yaitu evaluasi terhadap reaksi peserta. Penulis mengharapkan dari hasil penelitian ini dapat dijadikan bahan masukan bagi organisasi dalam memperbaiki sistem penyelenggaraan Diklat Dasar Jabatan Fungsional Penyuluh Perikananbaik Tingkat Ahli maupun Tingkat Terampil.

\section{METODE PENELITIAN}

Penelitian ini menggunakan metode deskriptif kualitatif. Metode deskriptif dilakukan untuk menggambarkan secara rinci tentang berjalannya suatu program diklat yang telah dilaksanakan. Pendekatan kualitatif dilakukan untuk menjelaskan evaluasi penyelengaraan diklat yang digambarkan berdasarkan hasil kuesioner yang telah dibagikan kepada peserta diklat. Efektivitas program diklat mencerminkan kepuasan peserta diklat terhadap layanan yang diberikan dengan melihat reaksi peserta diklat pada program diklat yang telah diikuti.

Analisis data dilakukan dengan menggunakan teknik komparatif. Teknik komparatif merupakan analisis yang sifatnya membandingkan persamaan dan perbedaan dua atau lebih sifat-sifat dan fakta- fakta objek yang diteliti. Teknik komparatif pada penelitian ini dilakukan untuk membandingkan reaksi peserta pada penyelenggaraan Diklat Dasar Jabatan Fungsional Penyuluh Perikanan Tingkat Ahli dan Tingkat Terampil pada tahun 2017 berdasarkan model Kirkpatrick pada level pertama.

Dalam menggambarkan evaluasi reaksi peserta pada penyelenggaraan diklat menggunakan skala penilaian dengan mengacu pada rentang skala sebagai berikut, Sangat Baik (9,1-10), Baik $(8,1-9,0)$, Cukup Baik $(7,1-8,0)$, Kurang Baik $(6,1-7,0)$ dan Tidak Baik $(\leq 6)$. Sumber data pada penelitian ini merupakan data primer yang diperoleh dari hasil kuesioner peserta diklat.

\section{HASIL DAN PEMBAHASAN}

\section{Hasil}

Penyelenggaraan Diklat Dasar Jabatan Fungsional Penyuluh Perikanan Tingkat Ahli di Balai Diklat Aparatur Kementerian Kelautan dan Perikanan telah dilaksanakan pada 7 - 17 Agustus 2017 yang diikuti oleh 39 orang. Peserta yang mengikuti diklat ini terdiri dari Penata Muda sebanyak 29 orang
(74,3\%), Penata Muda Tingkat I sebanyak 9 orang $(23,1 \%)$ dan Penata sebanyak 1 orang $(2,6 \%)$, kemudian menurut latar belakang yaitu lulusan S1 sebanyak 38 orang $(97,5 \%)$ dan S2 sebanyak satu orang (2,5\%). Untuk jumlah peserta diklat lakilaki berjumlah 20 orang $(51,3 \%)$ dan perempuan berjumlah 19 orang $(48,7 \%)$. 
Sedangkan penyelenggaraan Diklat Dasar Jabatan Fungsional Penyuluh Perikanan Tingkat Terampil dilaksanakan pada tanggal $21-31$ Agustus 2017 yang diikuti oleh 39 orang. Peserta yang mengikuti diklat ini terdiri dari Pengatur Muda sebanyak 11 orang $(28,2 \%)$, Pengatur Muda Tingkat I sebanyak 2 orang (5,1\%), Pengatur sebanyak 13 orang $(33,3 \%)$, Pengatur Tingkat I sebanyak 12 orang $(30,8 \%)$ dan Penata Muda sebanyak 1 orang $(2,6 \%)$. Peserta yang memiliki latar belakang pendidikan SMU atau sederajat berjumlah 18 orang $(46,2 \%)$ dan Diploma III sebanyak 21 orang $(53,8 \%)$. Untuk jumlah peserta diklat laki-laki berjumlah 21 orang $(53,8 \%)$ dan perempuan berjumlah 18 orang $(46,2 \%)$.

Evaluasi reaksi peserta pada penyelenggaraan Diklat Dasar Jabatan Fungsional Penyuluh Perikanan Tingkat Ahli dan Diklat Dasar Jabatan Fungsional Penyuluh Perikanan Tingkat Terampil pada dasarnya dilaksanakan untuk mengukur kepuasan peserta diklat tersebut. Peserta akan termotivasi apabila proses pelatihan berjalan memuaskan yang pada akhirnya akan memunculkan reaksi dari peserta yang menyenangkan. Sebaliknya, apabila peserta tidak merasa puas terhadap proses pelatihan yang diikutinya maka mereka tidak akan termotivasi untuk mengikuti kegiatan pelatihan lebih lanjut.Unsurunsur yang dinilai terhadap reaksi peserta Diklat Dasar Jabatan Fungsional Penyuluh Perikanan Tingkat Ahli dan Diklat Dasar Jabatan Fungsional Penyuluh Perikanan Tingkat Terampil terdiri dari (1) kurikulum, (2) tempat belajar, (3) asrama, (4) layanan panitia, (5) menu makanan, dan (6) pengaturan waktu. Hasil evaluasi reaksi peserta terhadap seluruh unsur penilaian tersebut meliputi kurikulum, tempat belajar, tempat menginap/asrama, layanan panitia, menu makanan, dan pengaturan waktu.

Kurikulum Diklat Dasar Jabatan Fungsional Penyuluh Perikanan Tingkat Ahli dan Diklat Dasar Jabatan Fungsional Penyuluh Perikanan Tingkat Terampil dinilai dari unsur yang terdiri dari penilaian terhadap ketersediaan bahan ajar, ketersediaan media pembelajaran, kualitas bahan ajar, kesesuaian materi dengan tujuan diklat, meningkatnya pengetahuan terhadap materi, dan meningkatnya keterampilan terhadap materi. Sesuai hasil kuesioner yang telah diisi oleh responden terhadap unsur kurikulum diperoleh data yang disajikan dalam bentuk grafik seperti yang terlihat pada Gambar 1.

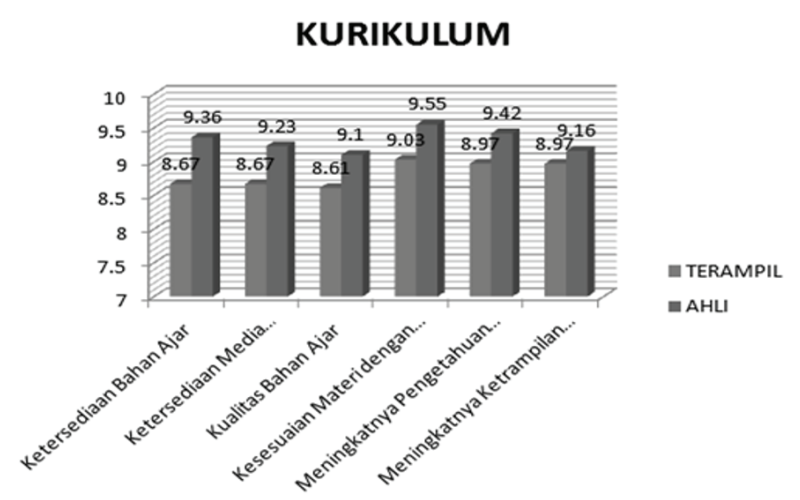

Gambar 1. Unsur kurikulum

Seluruh aspek pada unsur kurikulum Diklat Dasar Jabatan Fungsional Penyuluh Perikanan Tingkat Ahli memperoleh nilai minimal 9,1. Aspek kesesuaian materi dengan tujuan diklat memperoleh nilai yang paling tinggi yaitu 9,55 , sedangkan aspek kualitas bahan ajar memperoleh nilai yang paling rendah yaitu 9,1. Apabila unsur kurikulum dirataratakan diperoleh nilai 9,36 yang berarti sangat baik. Maknanya adalah bahwa kurikulum yang sudah digunakan saat ini menurut responden sudah sangat relevan atau memadai. Namun apabila akan dilakukan review terhadap kurikulum agar lebih difokuskan pada aspek kualitas bahan ajar karena memperoleh penilaian yang paling rendah.

Seluruh aspek pada unsur kurikulum Diklat Dasar Jabatan Fungsional Penyuluh Perikanan Tingkat Terampil memperoleh penilaian kurang dari 9,1. Aspek kesesuaian materi dengan tujuan diklat memperoleh nilai paling tinggi yaitu 9,03 , sedangkan aspek kualitas bahan ajar memperoleh nilai paling rendah yaitu 8,61. Apabila unsur kurikulum dirataratakan diperoleh nilai 8,82 yang artinya baik. Maknanya adalah kurikulum yang digunakan saat ini menurut responden sudah memadai namun masih perlu diperbaiki. Perbaikan terhadap kurikulum harus menyentuh seluruh aspek yang ada, terutama pada aspek kualitas bahan ajar yang memperoleh nilai terendah.

Sebagaimana penjelasan tersebut, maka kualitas bahan ajar pada Diklat Dasar Jabatan Fungsional Penyuluh Perikanan baik tingkat ahli maupun tingkat terampil yang digunakan saat ini masih perlu diperbaiki. Bahan ajar mempunyai peran penting dalam proses pembelajaran di kelas karena menjadi acuan yang digunakan oleh widyaiswara untuk menyampaikan materi kepada peserta diklat. Bagi widyaiswara, bahan ajar menjadi acuan yang diserap isinya sehingga dapat menjadi 
pengetahuan, sedangkan bagi peserta diklat, bahan ajar dapat digunakan sebagai media untuk proses belajar secara mandiri. Setelah selesai mengikuti diklat, peserta dapat membuka kembali bahan ajar diklatnya untuk mengumpulkan kembali informasi yang sudah diperoleh saat mengikuti diklat.

Perlu diketahui bahwa bahan ajar berpengaruh terhadap kualitas hasil belajar (Sugiarti, 2013) sehingga dapat dipastikan bahwa kualitas bahan ajar merupakan satu hal yang sangat penting dalam keberhasilan penyelenggaraan diklat. Semakin baik kualitas bahan ajar maka semakin baik pula kualitas hasil belajar peserta diklat. Sebaliknya, apabila kualitas bahan ajar dinilai masih kurang maka kualitas hasil belajar juga akan kurang berkualitas. Perbaikan mengenai kualitas bahan ajar lebih diupayakan dari sisi substansi. Substansi bahan ajar merupakan pokok-pokok uraian untuk mencapai standar kompetensi yang ingin dicapai dalam proses pembelajaran. Oleh sebab itu, substansi bahan ajar harus disusun sesuai dengan standar. Agar kualitas bahan ajar ini dapat disusun lebih efektif untuk mencapai tujuan pembelajaran maka perbaikan kualitas bahan ajar perlu mengacu pada sisi ketepatan isi, kedalaman isi, dan proporsi isi antara penjelasan teori dan praktik.

Ketepatan isi merupakan keabsahan bahan ajar sesuai dengan fakta sebenarnya, sesuai dengan praktik yang ada di lapangan. Bahan ajar yang sudah terlalu lama juga perlu disesuaikan kembali dengan kondisi faktual dan relevansinya dengan kegiatan penyuluhan yang berkembang saat ini. Perkembangan teknologi dan informasi yang semakin maju membuat banyak perubahan termasuk dalam kegiatan penyuluhan, sehingga perlu dipastikan kembali ketepatan isi baik dari sisi teoretis maupun praktis sesuai kondisi kekinian.

Peserta Diklat Dasar Jabatan Fungsional Penyuluh Perikanan baik tingkat ahli maupun tingkat terampil memiliki latar belakang yang heterogen, baik dari segi umur maupun pengalaman menyuluh. Sesuai dengan fakta tersebut maka kedalaman isi bahan ajar juga harus mengakomodir perbedaanperbedaan tersebut. Isi bahan ajar dapat lebih substantif dengan menyajikan praktik-praktik dalam kegiatan penyuluhan melalui studi kasus sebagai bahan diskusi peserta.

Diklat Dasar Jabatan Fungsional merupakan media bagi peserta untuk memenuhi persyaratan jabatan. Dalam rangka mewujudkan hal tersebut, bahan ajar didesain agar widyaiswara dan peserta lebih banyak melaksanakan praktik. Melalui praktik, peserta akan ikut terlibat dan memperoleh pengalaman langsung yang dapat bermanfaat baginya saat turun ke lapangan untuk melaksanakan penyuluhan.

Tempat belajar pada Diklat Dasar Jabatan Fungsional Penyuluh Perikanan Tingkat Ahli dan Diklat Dasar Jabatan Fungsional Penyuluh Perikanan Tingkat Terampil terdiri dari tata ruang, kenyamanan, keamanan, kebersihan dan kelengkapan fasilitas belajar. Sesuai hasil kuesioner yang telah diisi oleh responden terhadap unsur tempat belajar diperoleh data yang disajikan dalam bentuk grafik seperti terlihat pada Gambar 2.

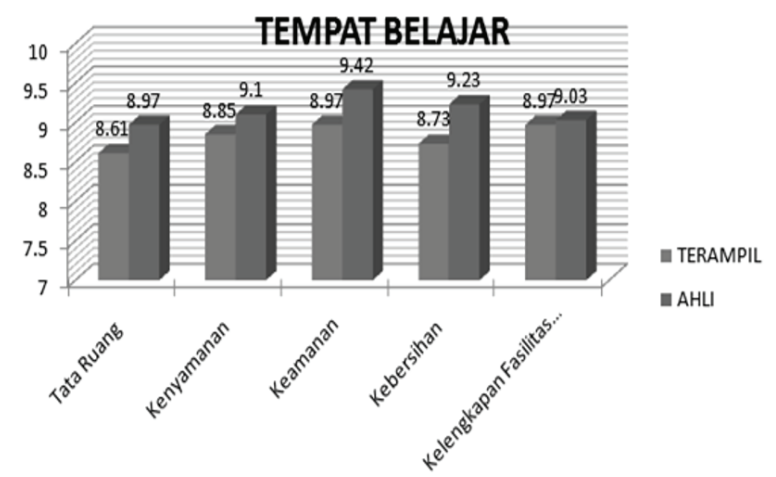

Gambar 2. Unsur tempat belajar

Seluruh aspek pada unsur tempat belajar Diklat Dasar Jabatan Fungsional Penyuluh Perikanan Tingkat Ahli memperoleh penilaian yang beragam. Aspek keamanan memperoleh nilai paling tinggi yaitu 9,42 , sedangkan aspek tata ruang kelas memperoleh penilaian paling rendah yaitu 8,97. Apabila unsur tempat belajar pada Diklat Dasar Penyuluh Perikanan Tingkat Ahli dirata-ratakan diperoleh nilai 9,15 yang berarti sangat baik. Maknanya adalah bahwa tempat belajar yang digunakan oleh responden pada saat mengikuti diklat sudah sangat relevan.

Seluruh aspek tempat belajar Diklat Dasar Jabatan Fungsional Penyuluh Perikanan Tingkat Terampil memperoleh penilaian kurang dari 9,1. Aspek keamanan dan aspek kelengkapan fasilitas belajar dan pembelajaran memperoleh penilaian paling tinggi yaitu 8,97 , sedangkan aspek tata ruang kelas memperoleh penilaian paling rendah yaitu 8,61. Apabila unsur tempat belajar dirata-ratakan diperoleh nilai 8,82 dengan kategori baik. Maknanya adalah bahwa masih diperlukan peningkatan tempat belajar di kelas, terutama pada aspek penataan 
ruang yang memperoleh nilai terendah.

Berdasarkan penjelasan di atas, aspek tata ruang kelas pada pelaksanaan Diklat Dasar Jabatan Fungsional Tingkat Ahli dan Tingkat Terampil mendapatkan penilaian yang paling rendah jika dibandingkan dengan aspek lainnya, sehingga untuk meningkatkan kualitas penyelenggaraan diklat pada unsur tempat belajar dapat dimulai dari perbaikan tata ruang terlebih dahulu. Perbaikan tata ruang kelas dapat melihat bagaimana tata ruang kelas pada lembaga diklat lain atau membandingkan dengan ruangan kelas tempat pelatihan pihak swasta. Ruangan kelas yang ada sekarang merupakan ruangan kelas dengan desain lama, sehingga perlu strategi bagaimana penataan ruang kelas yang relevan. Sementara penataan ruangan kelas sangat penting dalam menunjang proses pembelajaran.

Terdapat pengaruh yang signifikan antara penataan ruang kelas dengan prestasi belajar (Firdaus dkk, 2016). Salah satu upaya untuk meningkatkan prestasi belajar peserta diklat dapat dilakukan dengan cara melakukan penataan ruang kelas. Oleh karena itu penyelenggara diklat diharapkan lebih memperhatikan tata ruang kelas. Hal ini perlu dilakukan mengingat ruangan kelas yang digunakan oleh peserta Diklat Dasar Jabatan Fungsional Tingkat Ahli dan Tingkat Terampil merupakan ruangan kelas yang digunakan juga untuk pelaksanaan diklat lainnya, baik diklat teknis maupun diklat kepemimpinan. Apabila hal itu dilakukan, penataan ruang kelas dan isinya akan dapat memudahkan terjadinya interaksi yang aktif antara widyaiswara dan peserta diklat serta antar sesama peserta diklat. Pada prinsipnya penataan tempat belajar yang baik harus mempertimbangkan keleluasaan pandangan, akses untuk bergerak, fleksibilitas, dan estetika.

Keleluasaan pandangan maksudnya penempatan barang tidak mengganggu pandangan seluruh orang yang berada di dalam ruang kelas, dengan demikian maka peserta diklat secara leluasa dapat memandang widyaiswara yang berdiri di depan, bahan tayang atau media pembelajaran yang digunakan serta aktivitas pembelajaran yang sedang berlangsung. Widyaiswara juga harus dapat memandang semua peserta diklat saat kegiatan pembelajaran berlangsung tanpa ada barang yang menghalangi.

Akses bergerak dalam kelas harus diperhatikan, seperti penataan ruang harus dapat memudahkan peserta diklat untuk melaksanakan aktvitas pembelajaran. Penataan ruang kelas harus mempertimbangkan jarak antara benda-benda yang dimungkinkan dapat mempersulit pergerakan orangorang yang berada di dalamnya. Salah satu hal tersebut misalnya penataan jarak meja dan tempat duduk perlu disesuaikan agar mudah dilewati. Sistem penataan meja dengan model island memang sangat baik, namun tetap harus memperhatikan jarak antara island yang satu dengan lainnya.

Fleksibilitas barang-barang di dalam kelas hendaknya mudah ditata dan dipindahkan. Hal ini dilakukan agar penyesuaian metode yang digunakan pada saat proses pembelajaran lebih mudah. Misalnya metode diskusi kelompok dengan anggotanya dalam jumlah besar, maka meja peserta dapat digabung untuk memudahkan penyelesaian tugas diskusinya.

Estetika dari penataan ruang kelas harus diperhatikan juga. Ruangan kelas ditata agar menyenangkan dan kondusif untuk kegiatan belajar. Ruang kelas yang indah dapat memberikan rasa nyaman sehingga peserta tidak merasa bosan berada di ruang kelas selama mengikuti sesi pembelajaran. Oleh karena itu, penyelenggara harus memperhatikan penempatan papan tulis, proyektor, flipchart, remot, pas bunga dan hiasan dinding di tempat yang tepat.

Tempat menginap/asrama pada Diklat Dasar Jabatan Fungsional Penyuluh Perikanan Tingkat Ahli dan Diklat Dasar Jabatan Fungsional Penyuluh Perikanan Tingkat Terampil terdiri dari beberapa unsur, yaitu kenyamanan, kebersihan, keamanan, dan kelengkapan fasilitas. Sesuai hasil kuesioner yang telah diisi oleh responden terhadap unsur asrama diperoleh data yang disajikan dalam bentuk grafik seperti terlihat pada Gambar 3.

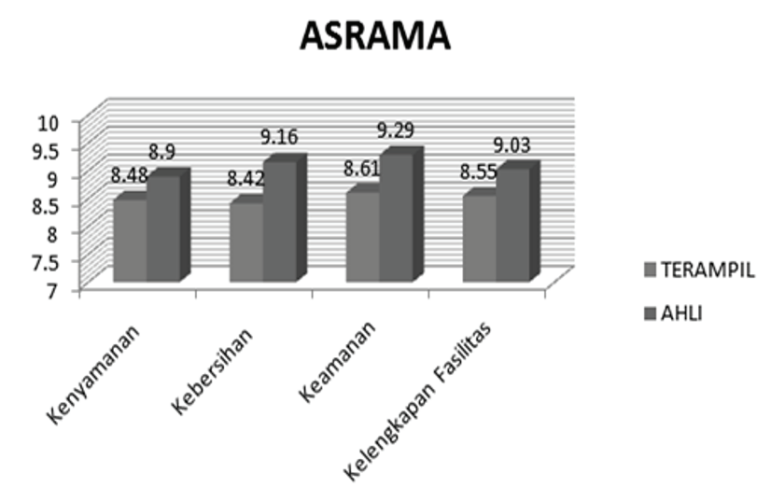

Gambar 3. Unsur asrama 
Seluruh aspek pada unsur asrama Diklat Dasar Jabatan Fungsional Penyuluh Perikanan Tingkat Ahli memperoleh penilaian yang beragam. Aspek keamanan memperoleh nilai yang paling tinggi yaitu 9,29, sedangkan aspek kenyamanan memperoleh nilai yang paling rendah yaitu 8,9 . Apabila unsur asrama dirata-ratakan diperoleh nilai 9,1 yang artinya sangat baik. Maknanya adalah asrama yang digunakan dalam pelaksanaan diklat sudah sangat memadai. Namun dari hasil penilaian terlihat bahwa aspek kenyamanan memperoleh penilaian paling rendah jika dibandingkan dengan aspek lainnya, sehingga peningkatan nilai pada unsur asrama diharapkan lebih memperhatikan aspek kenyamanan peserta diklat.

Seluruh aspek pada unsur asrama Diklat Dasar Jabatan Fungsional Penyuluh Perikanan Tingkat Terampil memperoleh penilaian kurang dari 9,1 . Aspek keamanan memperoleh nilai paling tinggi yaitu 8,61, sedangkan aspek kebersihan memperoleh nilai yang paling rendah yaitu 8,42 . Apabila seluruh aspek pada unsur asrama dirata-ratakan diperoleh nilai 8,52 yang artinya baik. Maknanya adalah asrama yang digunakan oleh peserta diklat sudah memadai. Untuk peningkatan nilai asrama maka salah satu cara yang dapat dilakukan adalah dengan meningkatkan kebersihannya. Aspek kebersihan lebih diprioritaskan mengingat aspek tersebut mendapatkan penilaian yang paling rendah.

Berdasarkan penjelasan tersebut maka penyelenggara harus melakukan penyesuaian terhadap kondisi asrama yang merupakan tempat tinggal atau menginap bagi peserta Diklat Dasar Jabatan Fungsional Penyuluh Perikanan Tingkat Ahli dan Tingkat Terampil. Kondisi asrama yang nyaman dan bersih tentu dapat berpengaruh terhadap motivasi peserta diklat.

Febriyanti (2014) menyebutkan bahwa terdapat hubungan yang signifikan antara lingkungan belajar dengan motivasi belajar. Selain digunakan sebagai tempat isitirahat, asrama juga memiliki fungsi lain yaitu sebagai tempat bagi peserta diklat untuk melaksanakan proses belajar secara mandiri. Kegiatan pembelajaran yang berakhir di kelas akan dilanjutkan peserta pada saat berada di asrama. Antar peserta dapat melaksanakan diskusi dengan topik materi yang sudah diperoleh di kelas. Peserta juga dapat melaksanakan tugas yang menuntutnya harus diselesaikan di asrama karena akan dikumpulkan atau dibahas esok harinya. Oleh karena itu, kondisi asrama memiliki peranan yang sangat vital, jika kondisi asrama sangat baik maka gairah belajar peserta juga meningkat. Namun apabila kondisi asrama kurang baik maka gairah belajar juga akan menurun. Oleh karena itu, pihak penyelenggara harus memastikan bahwa kenyamanan, keamanan, kebersihan, dan fasilitas yang ada di asrama harus memadai. Untuk memastikan hal tersebut sebenarnya sangat mudah, penyelenggara dapat melaksanakan fungsi controlling atas seluruh aspek tersebut. Pastikan bahwa peserta merasa nyaman dan aman selama menggunakan asrama serta fasilitas yang ada di asrama dapat digunakan seluruhnya. Untuk mewujudkan hal tersebut dapat dilakukan dengan cara melakukan pengecekan terhadap fasilitas asrama. Penyelenggara juga harus memastikan bahwa peserta dapat mengakses internet dari asrama. Hal ini perlu dilakukan untuk memberikan kemudahan peserta diklat dalam melaksanakan proses belajar mandiri dan penyelesaian tugas di asrama.

Layanan panitia pada Diklat Dasar Jabatan Fungsional Penyuluh Perikanan Tingkat Ahli dan Diklat Dasar Jabatan Fungsional Penyuluh Perikanan Tingkat Terampil terdiri dari beberapa unsur, yaitu layanan adminsitrasi diklat, keramahan, dan kesigapan. Sesuai hasil kuesioner yang telah diisi oleh responden terhadap unsur asrama diperoleh data yang disajikan dalam bentuk grafik seperti terlihat pada Gambar 4.

\section{LAYANAN PANITIA}

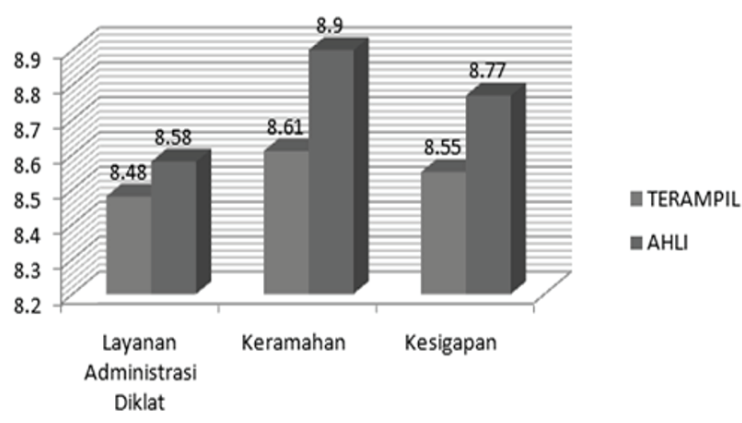

Gambar 4. Unsur layanan panitia

Seluruh aspek pada unsur layanan panitia Diklat Dasar Jabatan Fungsional Penyuluh Perikanan Tingkat Ahli memperoleh penilaian kurang dari 9,1. Aspek karamahan peserta memperoleh penilaian paling tinggi yaitu 8,9 , sedangkan aspek layanan administrasi diklat memperoleh nilai paling rendah 
yaitu 8,58. Apabila dirata-ratakan maka unsur layanan panitia memperoleh nilai 8,77 yang artinya baik. Maknanya adalah perlu dilakukan perbaikan pelayanan panitia kepada peserta diklat.

Seluruh aspek pada unsur layanan panitia pada Diklat Dasar Jabatan Fungsional Penyuluh Perikanan Tingkat Terampil juga memperoleh penilaian kurang dari 9,1. Aspek keramahan memperoleh penilaian paling tinggi yaitu 8,61 , sedangkan aspek layanan administrasi diklat memperoleh penilaian paling rendah yaitu 8,48 . Apabila dirata-ratakan maka unsur layanan panitia memperoleh nilai 8,55 yang artinya baik.

Sesuai hasil penilaian tersebut dapat diketahui bahwa layanan administrasi diklat pada penyelenggaraan Diklat Dasar Jabatan Fungsional Penyuluh Perikanan Tingkat Ahli dan Diklat Dasar Jabatan Fungsional Penyuluh Perikanan Tingkat Terampil memperoleh penilaian paling rendah. Layanan administrasi diklat meliputi layanan persyaratan peserta, absensi peserta, pendataan kepulangan peserta, dan layanan penggantian biaya transportasi peserta. Pada aspek lainnya, responden memiliki penilaian yang sama terhadap keramahan dan kesigapan yang diberikan panitia masih belum maksimal. Berdasarkan hal tersebut, secara keseluruhan penilaian layanan panitia masih perlu ditingkatkan, baik dari aspek layanan administrasi, keramahan, maupun kesigapan panitia. Layanan panitia berpengaruh terhadap kepuasan peserta diklat yang notabene merupakan pelanggan dari sebuah lembaga diklat.

Ismerisa (2013) menunjukkan bahwa kualitas pelayanan berpengaruh secara signifikan terhadap kepuasan pelanggan. Berdasarkan hasil penelitian tersebut maka dapat dipastikan bahwa pelayanan panitia sangat berpengaruh terhadap kepuasan peserta diklat. Apabila pelayanan panitia sangat baik maka peserta akan memperoleh kepuasan yang maksimal atas layanan tersebut, sebaliknya apabila pelayanan yang diberikan kepada peserta kurang maksimal maka kepuasan yang diterima peserta juga berkurang. Mengingat pelayanan panitia sangat menentukan dalam memberikan kepuasan kepada peserta diklat, maka penyelenggara harus mampu memaksimalkan setiap aspek pelayanan. Apabila pelayanan yang diberikan dirasa kurang maksimal, hal ini dikhawatirkan memberikan dampak yang panjang mengingat peserta diklat yang sama akan mengikuti kegiatan diklat lainnya di Balai Diklat Aparatur. Peserta diklat bisa saja sudah beranggapan negatif terlebih dahulu atas pelayanan panitia. Untuk mengantisipasi hal tersebut maka panitia dalam memberikan pelayanan kepada peserta diklat harus menunjukkan beberapa sikap, seperti lebih responsif, bersedia mendengarkan keluhan, menjaga kesabaran, serta lebih ramah.

Dalam memberikan pelayanan kepada peserta diklat, respon panitia merupakan kunci utama dari kepuasan peserta diklat. Penyelenggara harus berani memastikan bahwa panitia memiliki respon yang cepat dalam menyelesaikan keluhan peserta diklat. Panitia juga harus bersedia memberikan waktu ekstra untuk memberikan pelayanan prima kepada peserta diklat.

Hal yang sering terjadi dalam memberikan pelayanan kepada peserta diklat adalah adanya keluhan. Sebagai panitia sudah seharusnya bersedia mendengarkan setiap keluhan peserta. Terkadang peserta tidak menyampaikan secara langsung seperti melalui kotak saran, namun sebagai panitia keluhan tetaplah keluhan harus segera diatasi.

Sebagai panitia harus menyadari bahwa peserta diklat merupakan komunitas yang heterogen yang memiliki karakteristik yang berbeda-beda. Dengan karakteristik yang berbeda-beda tersebut terkadang panitia menemukan peserta diklat yang ingin serba cepat atau hal-hal lain yang terkadang membutuhkan kesabaran lebih. Dalam hal ini, panitia harus mampu menjaga kesabaran dalam memberikan pelayanan kepada semua peserta diklat tanpa membedakan karakternya.

Keramahan merupakan hal yang sangat penting saat berinterkasi dengan peserta diklat baik secara langsung maupun tidak. Sikap ramah bisa ditunjukkan melalui penggunaan bahasa yang baik. Keramahan dapat ditunjukkan dengan gestur tubuh yang baik saat memberikan pelayanan.

Menu makanan pada peserta Diklat Dasar Jabatan Fungsional Penyuluh Perikanan Tingkat Ahli dan Diklat Dasar Jabatan Fungsional Penyuluh Perikanan Tingkat Terampil dinilai berdasarkan kuantitas, kualitas, variasi, dan kebersihan. Sesuai hasil kuesioner yang telah diisi oleh responden terhadap unsur menu makanan diperoleh data yang disajikan dalam bentuk grafik seperti terlihat pada Gambar 5. 


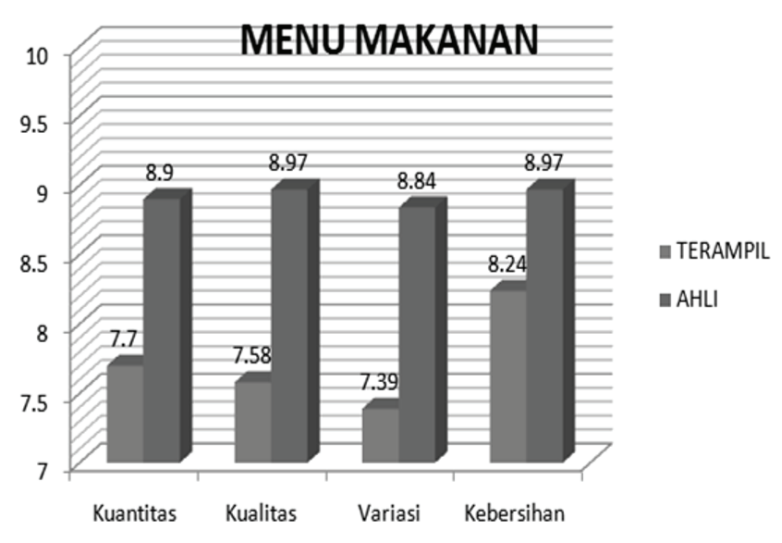

Gambar 5. Unsur menu makanan

Seluruh aspek pada unsur menu makanan Diklat Dasar Jabatan Fungsional Penyuluh Perikanan Tingkat Ahli memperoleh penilaian kurang dari 9,1 . Aspek kualitas dan kebersihan memperoleh penilaian paling tinggi yaitu 8,97, sedangkan aspek variasi memperoleh penilaian paling rendah yaitu 8,84 . Apabila seluruh aspek penilaian tersebut dirata-ratakan diperoleh nilai 8,92 yang artinya baik. Maknanya adalah menu makanan yang disajikan pada peserta Diklat Dasar Jabatan Fungsional Penyuluh Perikanan Tingkat Ahli sudah sesuai namun masih harus ditingkatkan.

Seluruh aspek pada unsur menu makanan Diklat Dasar Jabatan Fungsional Penyuluh Perikanan Tingkat Terampil, memperoleh penilaian kurang dari 9,1. Aspek kebersihan memperoleh penilaian paling tinggi yaitu 8,24 , sedangkan aspek variasi memperoleh penilaian paling rendah yaitu 7,39 . Apabila seluruh aspek unsur menu makanan dirataratakan diperoleh nilai 7,72 yang artinya cukup baik. Maknanya adalah masih perlu peningkatan menu makanan yang disajikan kepada peserta diklat terutama untuk aspek, kuantitas, kualitas dan variasi makanan. Ketiga aspek tersebut mendapatkan penilaian yang rendah dari responden, sehingga diperlukan adanya perubahan yang berarti terhadap menu makanan yang disajikan kepada peserta diklat.

Gambar 5 menunjukkan bahwa seluruh aspek pada unsur menu makanan pada Diklat Dasar Jabatan Fungsional Penyuluh Perikanan Tingkat Terampil memperoleh nilai lebih rendah daripada Diklat Dasar Jabatan Fungsional Penyuluh Perikanan Tingkat Ahli.

Aspek variasi menu makanan pada pelaksanaan Diklat Dasar Jabatan Fungsional
Penyuluh Perikanan Tingkat Ahli dan Tingkat Terampil memperoleh penilaian paling rendah apabila dibandingkan dengan aspek penilaian lainnya, sehingga perbaikan dapat dilakukan dengan lebih memfokuskan pada variasi menu makanan. Sesuai kondisi faktual di lapangan, menu makanan yang disajikan juga diberikan kepada peserta diklat lain bahkan menu makanan tersebut disajikan sepanjang tahun. Apabila tidak segera dilakukan perbaikan maka penilaian terhadap menu makanan akan terus rendah dan hal ini mempengaruhi penilaian terhadap kualitas penyelenggaraan diklat. Mengingat peserta diklat berasal dari daerah yang berbeda-beda, maka hal ini patut dijadikan bahan pertimbangan dalam menentukan variasi makanan. Satu hal yang paling penting dalam menentukan menu makanan yaitu mengenai kesehatan makanannya.

Makanan yang sehat merupakan makanan yang tepat untuk menambah nutrisi bagi tubuh kita, yang didalamnya terkandung zat-zat gizi. Zat-zat gizi tersebut yaitu karbohidrat, protein, lemak, vitamin, mineral dan air (Hardani, 2002). Merujuk pada hal tersebut maka menu makanan wajib memenuhi nutrisi yang dibutuhkan oleh tubuh. Apabila menu makanan sudah memenuhi kewajiban tersebut, maka hal lain yang harus diperhatikan adalah mengenai daftar menu makanan. Terkait dengan hal ini, penyediaan daftar menu makanan dapat membandingkan dengan daftar menu makanan yang disajikan pada lembaga diklat lain. Melalui tindakan studi banding akan diperoleh informasi yang jelas mengenai daftar menu makanan dalam satu minggu bahkan mungkin dalam satu bulan. Sebagai lembaga diklat pemerintah, penyediaan menu makanan juga harus disesuaikan dengan ketersediaan anggaran, sehingga melalui kedua hal ini akan diperoleh titik temu mengenai menu makanan yang sesuai dengan ketersediaan anggaran.

Pengaturan waktu yang diberikan pada peserta Diklat Dasar Jabatan Fungsional Penyuluh Perikanan Tingkat Ahli dan Diklat Dasar Jabatan Fungsional Penyuluh Perikanan Tingkat Terampil terdiri dari beberapa unsur, yaitu jumlah waktu yg dialokasi untuk materi, jumlah waktu tes, dan jumlah waktu istirahat. Sesuai hasil kuesioner yang telah diisi oleh responden terhadap unsur pengaturan waktu diperoleh data yang disajikan dalam bentuk grafik seperti terlihat pada Gambar 6 . 


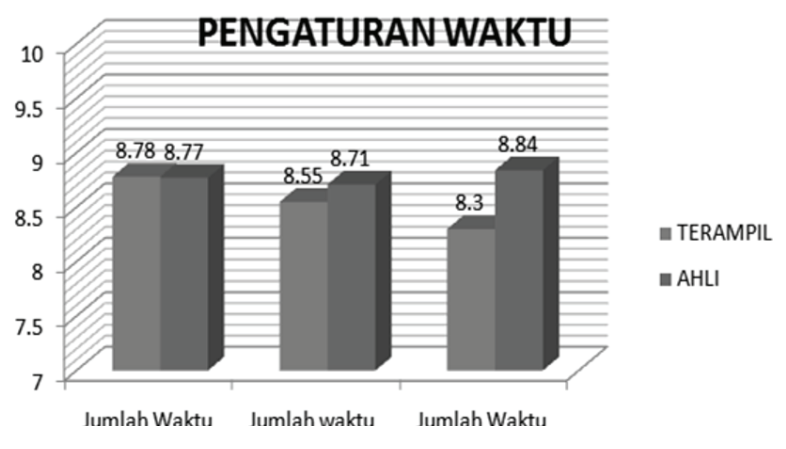

Gambar 6. Unsur Pengaturan Waktu

Seluruh aspek pada unsur pengaturan waktu Diklat Dasar Jabatan Fungsional Penyuluh Perikanan Tingkat Ahli memperoleh nilai yang hampir sama. Aspek jumlah waktu istirahat memperoleh nilai paling tinggi yaitu 8,84 , sedangkan aspek jumlah waktu tes memperoleh nilai paling rendah yaitu 8,71 . Apabila aspek unsur pengaturan waktu dirata-ratakan diperoleh nilai 8,77 yang artinya baik. Maknanya adalah masih perlu ditinjau kembali pengaturan waktu yang diberikan kepada peserta diklat.

Seluruh aspek pada unsur pengaturan waktu Diklat Dasar Jabatan Fungsional Penyuluh Perikanan Tingkat Terampil memperoleh penilaian dibawah 9,1. Aspek jumlah waktu yang dialokasi untuk materi memperoleh nilai paling tinggi yaitu 8,78 , sedangkan aspek jumlah waktu untuk istirahat memperoleh nilai paling rendah yaitu 8,3 . Apabila unsur pengaturan waktu dirata-ratakan diperoleh nilai 8,54 yang artinya baik. Maknanya adalah masih perlu ditinjau kembali pengaturan waktu atau jadwal pelaksanaan diklat yang diberikan kepada peserta diklat.

Berdasarkan penjelasan di atas dapat diketahui bahwa unsur pengaturan waktu dalam pelaksanaan Diklat Dasar Jabatan Fungsional Penyuluh Perikanan Tingkat Ahli dan Tingkat Terampil masih perlu diperbaiki. Pengaturan waktu merupakan hal yang sangat penting dalam mengatur aktivitas peserta selama mengikuti diklat. Melalui pengaturan waktu, peserta akan memperoleh alokasi untuk belajar di kelas dan istirahat di asrama. Terkait dengan hal ini maka panitia harus mampu mengatur jadwal diklat secara tepat dan presisi. Maksudnya, pembagian waktu harus sesuai dengan pemenuhan kebutuhan kurikulum diklat tetapi juga tidak mengesampingkan alokasi waktu istirahat bagi peserta diklat. Untuk itu pengaturan jadwal diklat harus seimbang untuk memenuhi kedua hal tersebut.

Salah satu faktor yang menyebabkan sukses atau tidaknya suatu proses pembelajaran adalah waktu belajar. Semakin tepat waktu belajar maka semakin baik hasil belajarnya (Lestari, 2013). Hasil penelitian menunjukkan bahwa waktu belajar berpengaruh signifikan terhadap hasil belajar. Merujuk pada hal tersebut maka pengaturan jadwal diklat harus dilakukan dengan benar dan tidak asal jadi.

Pengaturan jadwal diklat dilakukan pada masa persiapan diklat dengan berpedoman pada kurikulum diklat. Berdasarkan jadwal diklat yang telah disusun, proses pembelajaran Diklat Dasar Jabatan Fungsional Tingkat Ahli dan Tingkat Terampil dimulai pada pagi hari pukul 07.30 WIB. Dalam satu hari, peserta akan mengikuti proses pembelajaran selama 3 sesi yaitu pukul $07.30-09.45,10.00-$ 12.15 dan $13.00-15.15$.

Pada sela-sela sesi, peserta akan mendapatkan waktu istirahat sebanyak 3 kali yaitu dua kali coffe break selama 15 menit dan satu kali istirahat sholat dan makan siang selama 45 menit. Namun sesuai dengan jadwal yang telah disusun tersebut terdapat proses pembelajaran pada Diklat Dasar Jabatan Fungsional Tingkat Ahli sampai dengan lima sesi sehingga berakhir pada pukul 21.00 WIB, sedangkan pada proses pembelajaran Diklat Dasar Jabatan Fungsional Penyuluh Perikanan Tingkat Terampil terdapat satu hari yang berakhir pada pukul 20.15 WIB.

Menurut Darwin (2017), proses pembelajaran diklat sampai dengan malam hari tidak efektif karena peserta sudah tidak antusias dan merasa lelah. Proses pembelajaran yang sampai dengan malam hari juga sering menjadi keluhan peserta diklat. Hal ini disebabkan karena peserta menggunakan waktu malam hari untuk istirahat dan proses belajar mandiri di asrama. Sesuai hal tersebut maka pengaturan jadwal diklat sebaiknya tidak sampai dengan malam hari. Hal ini dilakukan agar peserta dapat menggunakan waktu istirahatnya dengan baik sehingga dapat lebih siap untuk proses pembelajaran berikutnya. 


\section{PENUTUP}

\section{Kesimpulan}

Mengacu pada paparan empiris pada penelitian ini, maka dapat diambil beberapa kesimpulan mengenai respon peserta pada penyelenggaraan Diklat Dasar Jabatan Fungsional Penyuluh Perikanan Tingkat Ahli dan Tingkat Terampil. Rata-rata respon peserta Diklat Dasar Jabatan Fungsional Penyuluh Perikanan Tingkat Ahli pada unsur kurikulum diperoleh nilai 9,36 . Rata-rata respon peserta pada unsur penilaian lainnya yaitu tempat belajar $(9,15)$, asrama $(9,1)$, layanan panitia $(8,77)$, menu makanan $(8,92)$, dan pengaturan waktu $(8,77)$. Respon peserta tersebut memiliki makna bahwa unsur kurikulum tempat belajar, dan asrama sudah sangat memadai sedangkan unsur layanan panitia, menu makanan, pengaturan waktu masih perlu dilakukan perbaikan, sedangkan rata-rata respon peserta Diklat Dasar Jabatan Fungsional Penyuluh Perikanan Tingkat Terampil pada unsur kurikulum diperoleh nilai 8,82. Kemudian rata-rata respon peserta pada unsur penilaian lainnya yaitu tempat belajar $(8,82)$, asrama $(8,52)$, layanan panitia $(8,55)$, menu makanan $(7,72)$, dan pengaturan waktu $(8,54)$. Respon peserta tersebut bermakna bahwa seluruh unsur penilaian baik kurikulum, tempat belajar, asrama, layanan panitia, menu makanan, dan pengaturan waktu masih perlu dilakukan perbaikan.

Saran

Saran yang dapat disampaikan adalah memperbaiki layanan panitia, menu makanan dan pengaturan jadwal diklat pada pelaksanaan Diklat
Dasar Jabatan Fungsional Penyuluh Perikanan Tingkat Ahli. Perbaikan terhadap layanan panitia dapat dilakukan dengan cara mengarahkan panitia agar lebih cepat dalam merespon, lebih ramah dalam memberikan pelayanan, dan lebih cepat dalam menyelesaikan layanan administrasi diklat. Perbaikan terhadap menu makanan dapat dilakukan dengan cara menyesuaikan daftar menu makanan agar lebih bervariasi tanpa mengurangi kualitas dan kuantitas makanannya. Perbaikan terhadap pengaturan jadwal diklat dilakukan dengan memastikan bahwa proses pembelajaran hanya sampai sore hari, artinya tidak ada proses pembelajaran pada malam hari.

Pada Diklat Dasar Jabatan Fungsional Penyuluh Perikanan Tingkat Terampil dapat dilakukan perbaikan terhadap seluruh unsur penilaian yaitu kurikulum, tempat belajar, asrama, layanan panitia, menu makanan, dan pengaturan jadwal. Perbaikan kurikulum diklat dapat dilakukan dengan mengembangkan substansi bahan ajar. Perbaikan terhadap tempat belajar dapat dilakukan dengan melakukan penataan ulang terhadap seluruh barang-barang yang ada di ruangan kelas. Perbaikan untuk asrama dapat dilakukan dengan cara memastikan bahwa seluruh fasilitas yang ada di asrama dapat digunakan. Perbaikan terhadap unsur layanan panitia, menu makanan, dan pengaturan waktu dilakukan dengan cara yang sama seperti pada Diklat Dasar Jabatan Fungsional Penyuluh Perikanan Tingkat Ahli.

\section{DAFTAR PUSTAKA}

Darwin. (2017). Efektivitas kediklatan. Jakarta: Badan Pendidikan dan Pelatihan Keuangan.

Febriyanti, A. (2014). Hubungan suasana lingkungan belajar dengan motivasi belajar siswa kelas V SD Negeri Gugus III Kota Bengkulu. Tesis. Fakultas Keguruan dan IImu Pendidikan (FKIP) Universitas Bengkulu.

Firdaus, R, dkk. (2016). Pengaruh penataan ruang kelas terhadap hasil belajar siswa kelas $\mathrm{V}$ (Study eksperimen di SDN 4 Kuripan Utara) tahun 2016. Skripsi. Fakultas Keguruan dan IImu Pendidikan (FKIP) Universitas Mataram.

Hardani, R. (2002). Pola makan sehat. Makalah
Seminar Online Kharisma ke-2. Yogyakarta: RS dr. Sardjito.

Ismerisa. (2013). Pengaruh pelayanan terhadap kepuasan pelanggan. Yogyakarta: UIN Sunan Kalijaga.

Kirkpatrick, D. L \& J.D., Kirkpatrick (2005). Evaluating training program. San Francisco, USA: BerretKoehler Publisher, Inc.

Lestari, Indah. (2013). Pengaruh waktu belajar dan minat belajar terhadap hasil belajar matematika. Jakarta: Universitas Indraprasta PGRI.

Peraturan Menteri Negara Pendayagunaan Aparatur 
Negara Nomor 19 tahun 2008 tentang Jabatan Fungsional Penyuluh Perikanan dan Angka Kreditnya.

Peraturan Pemerintah Nomor 101 tahun 2000 tentang Diklat Bagi PNS.

Slamet, M. (2000). Memantapkan posisi dan meningkatkan peran penyuluhan pembangunan dalam pembangunan. Prosiding Seminar IPB Bogor: Pemberdayaan Sumber Daya Manusia Menuju Terwujudnya Masyarakat Madani. Pustaka Wira Usaha
Muda.

Sugiarti, L. (2013). Pengaruh bahan ajar terhadap kualitas hasil belajar materi konstruksi pola pada prodi PKK tata busana. Fashion and Fashion Education Journal, 2(1), 48-54. https://journal.unnes.ac.id/sju/index.php/ffe/ article/view/2317

Undang-Undang Nomor 16 tahun 2006 tentang Sistem Penyuluhan Pertanian, Perikanan dan Kehutanan. 